\title{
Assessment of health risks related to groundwater consumption in Al- Hoceima region
}

\author{
Fatiha MCHIOUER ${ }^{1 *}$, Hossain EL OUARGHI ${ }^{1}$, Said BENYOUSSEF ${ }^{1,2}$ and Mustapha ABOURRICH ${ }^{1,3}$ \\ ${ }^{1}$ Laboratory for Water and Environmental Management Unit, National School of Applied Sciences, Abdelmalek Essaadi University, \\ 32003 Al Hoceima, Morocco \\ ${ }^{2}$ Research team: Biology, Environment and Health, Faculty of Science and Technology, Moulay Ismail University of Meknes, \\ Morocco \\ ${ }^{3}$ Office of Hygiene and Epidemiology, Health Establishment Network Service, Al-Hoceima Delegation
}

\begin{abstract}
Water is a precious natural resource for life, and more vulnerable to different contaminations; it has become less and less drinkable because it is polluted and can carry pathogenic germs that cause water diseases. The population of the Al-Hoceima region is supplied with drinking water from the network of the National Drinking Water Board, which is not widespread in rural areas where there is the frequent use of communal water points (spring or well). Health concerns remain related to the consumption of untreated well water, in the absence of a department responsible for the management of well water (development, equipment, treatment, protection, and quality control). To preserve the health of the population from any source of contamination carried by water, the Ministry of Health, carries out, through the provincial hygiene services, the control and monitoring of the physical-chemical and bacteriological quality of water in the framework of the fight against water diseases. The objective of this work was to determine the state of groundwater quality in the Al-Hoceima region, based on the study of physicochemical and bacteriological parameters. A control of 41 collective water points was carried out, including 30 wells and 11 springs. The collected samples were analyzed to measure some physical parameters: electrical conductivity, $\mathrm{pH}$, temperature, and dissolved oxygen, possibly looking for indicator germs of fecal contamination, namely coliform bacteria, Escherichia coli, and intestinal enterococci. The results revealed fecal contamination of all collective water points by coliform bacteria and Escherichia coli. Appropriate measures must be taken for the disinfection of these waters before their use.
\end{abstract}

\section{Introduction}

Access to healthy drinking water is an indispensable condition for human health. Thus, the importance of water, sanitation, and hygiene for health and development is reflected in the conclusions of a series of international forum [1]. Factors that could explain water pollution are the lack of a system for collecting, discharging, and treating wastewater and household waste, as well as defecation in nature and the infiltration of organic matter into the soil. Untreated or polluted water carries viruses, bacteria, parasites, and plant or animal micro-organisms that can cause serious diseases in humans. These diseases related to unsafe water are called waterborne diseases. The investments to improve water quality and sanitation worldwide are inadequate; the situation is still very critical. Today, nearly 2 billion people use a drinking water source contaminated with feces, putting them at risk of cholera, dysentery, typhoid, and poliomyelitis [2]. 1.5 million Children die each year from diarrhea, among other things, and one-third of these deaths could be prevented by providing adequate sanitation services [2]. In Morocco, groundwater constitutes an important part of the country's water resources [3], due to its relatively easy operation. In rural areas, groundwater is traditionally the preferred water resource for drinking water, as it is estimated to be less polluting than surface water. In our study area, groundwater has always been an important source of drinking water for local populations, and surface water is used for animal watering and irrigation. The challenge facing all regions of Morocco and especially rural areas is the protection of the quality of groundwater resources. Indeed, groundwater pollution is one of the most worrisome aspects and the use of groundwater for food purposes could in some cases represent a definite danger to human health [5]. Today, little data are available on the health status of drinking water supplies in rural municipalities in the province of Al- Hoceima. The majority of municipalities use well water and springs to meet their water needs. These wells can be constructed or not, as also water can be treated or not. These conditions increase the risk of acquiring

\footnotetext{
Corresponding author: fatiha.mchiouer@yahoo.fr
} 
waterborne diseases.

The evaluation aimed to achieve the following objectives: -Determine the bacteriological and physicochemical quality of water consumed in rural areas;

-Identify health issues related to groundwater consumption that threaten the population;

-Identify practices and other sources of environmental and drinking water nuisance to users.

In Morocco, groundwater constitutes an important part of the country's water resources [3], due to its relatively easy operation. In rural areas, groundwater is traditionally the preferred water resource for drinking water, as it is estimated to be less polluting than surface water. In our study area, groundwater has always been an important source of drinking water for local populations, and surface water is used for animal watering and irrigation.

The challenge facing all regions of Morocco and especially rural areas is the protection of the quality of groundwater resources. Indeed, groundwater pollution is one of the most worrisome aspects and the use of groundwater for food purposes could in some cases represent a definite danger to human health [5].

Today, little data are available on the health status of drinking water supplies in rural municipalities in the province of Al- Hoceima. The majority of municipalities use well water and springs to meet their water needs. These wells can be constructed or not, as also water can be treated or not. These conditions increase the risk of acquiring waterborne diseases. The evaluation aimed to achieve the following objectives:

-Determine the bacteriological and physicochemical quality of water consumed in rural areas;

-Identify health issues related to groundwater consumption that threaten the population;

-Identify practices and other sources of environmental and drinking water nuisance to users.

\section{MATERIALS AND METHODS}

\subsection{Area of study}

This study was conducted in northern Morocco. The province of Al Hoceima covers the central part of the Rif's chain. This set of heterogeneous and compartmentalized mountains constitutes the highest part (Jbel Tidghine $2456 \mathrm{~m}$ ) and the broadest part $(80 \mathrm{~km})$ of the Rif. It is made up of five municipalities and four circles that encompass 17 electoral districts containing 31 rural communes.

\subsection{Characterization of collective water points}

The water points were chosen based on the following criteria:

-Use as a communal water point by the population;
-Proximity to a wilderness landfill;

-Proximity to septic tanks

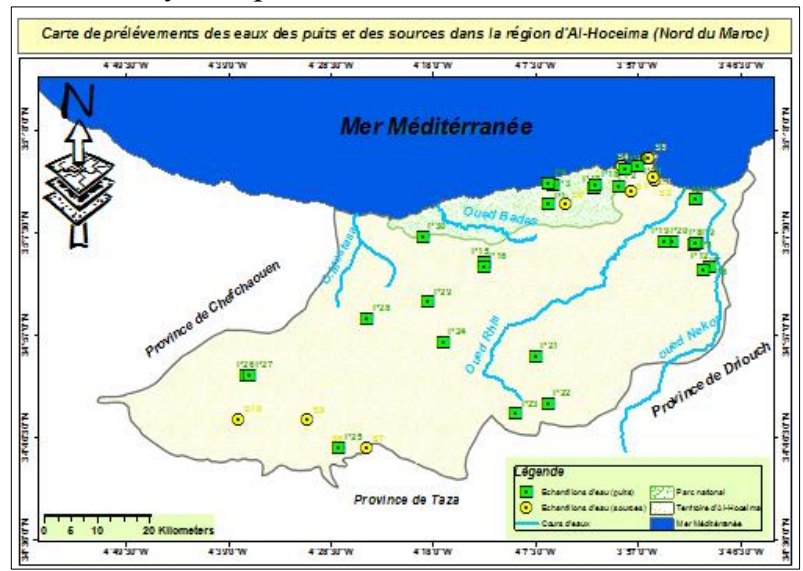

Fig. 1. The location of communal water points in the province of Al-Hoceima.

\subsection{Sample collection}

A control of 41 collective water points was carried out, including 30 wells and 11 springs. Samples collected were analyzed to immediately measure some physical parameters $\left(\mathrm{EC}, \mathrm{pH}, \mathrm{T}^{\circ} \mathrm{C}, \mathrm{DO}, \% \mathrm{O} 2\right.$ saturation) and search for germs indicating fecal contamination, such as coliform bacteria, Escherichia coli, and intestinal enterococci. The work consists of collecting samples while respecting the standards of precautions and conservation and then carrying out a series of physicochemical and bacteriological analyses based on the work guide of (Rodier, 2009) [6] by the membrane filtration method.

\section{RESULT AND DISCUSSION}

The majority of rural municipalities use well water and springs to meet their water needs. These wells can be constructed or not, as also water can be treated or not. These conditions increase the risk of acquiring waterborne diseases. (Figure 2). For installed wastewater systems, the majority of households (99\%) have anarchybuilt septic tank latrines (Figure 4). $70 \%$ of latrines are located at a distance of fewer than 15 meters from the source of water supply (minimum source-latrine distance recommended by the WHO).

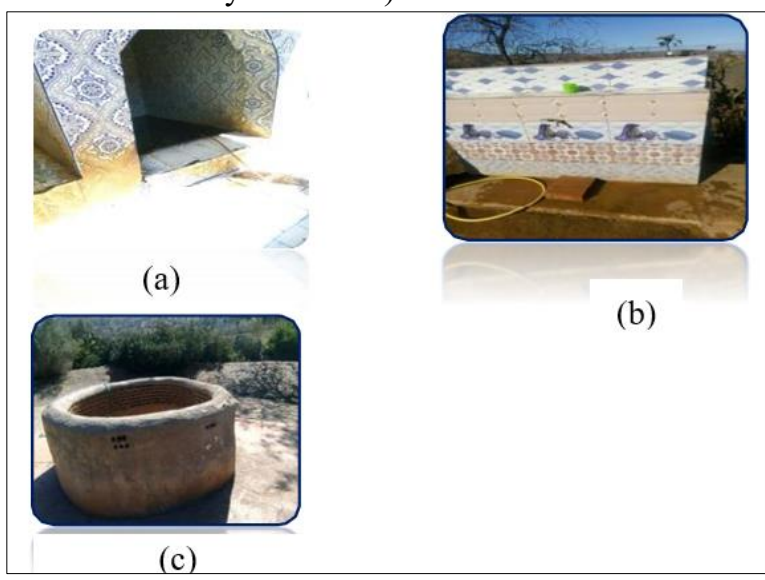

Fig. 2. The health status of some wells and springs used by the population in rural areas (a) unprotected spring (b). 


\subsection{Evolution of waterborne diseases and diarrhea in Al-Hoceima province}

Waterborne diseases are due to poor biological water quality, infectious diarrhea in particular cholera and shigellosis, typhoid fever, viral hepatitis A and E, to which must be added leptospirosis.

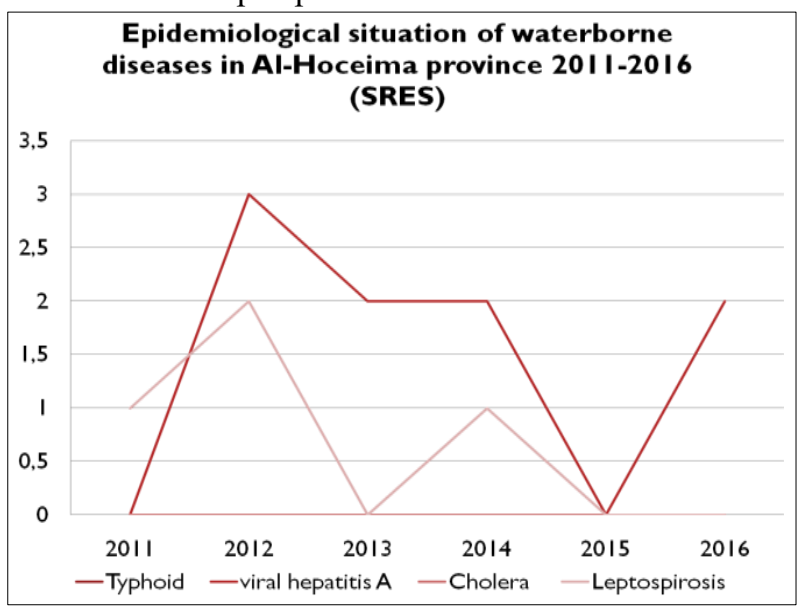

Fig. 3. Epidemiological situation of waterborne diseases in Al-Hoceima province 2011-2016

According to Fig. 3, no cases of typhoid and cholera have been reported in the Al-Hoceima region. The water-borne disease recorded is viral hepatitis, only two cases in 2016 deriving from the commune Ait youssef ouAli.

\subsection{Diarrhea in children under five years of age}

Childhood diarrhea is a public health problem due to the proliferation of enteric pathogens; the transmission of these germs is promoted not only by the conditions of the physical environment but also and above all by the noncompliance with hygiene measures, inadequate or dysfunctional sanitary infrastructure and public facilities for the disposal and treatment of wastewater, and inadequate supply of drinking water to households.

Table 1. Diarrhea in children under 5 years of age in AlHoceima Province (SRES)

\begin{tabular}{|l|l|l|l|}
\hline commune & 2016 & 2017 & 2018 \\
\hline Aityoussef ou ali & 40 & 196 & 73 \\
\hline Tmassint & 15 & 20 & 2 \\
\hline Nekkor & 33 & 94 & 131 \\
\hline Izamouren & 36 & 160 & 95 \\
\hline Rouadi & 30 & 22 & 122 \\
\hline Bni abdellah & 25 & 75 & 24 \\
\hline Bni hdifa & 61 & 38 & 133 \\
\hline Bniboufrah & 60 & 145 & 56 \\
\hline Bni gnil & 70 & 108 & 22 \\
\hline Bni ammart & 21 & 180 & 7 \\
\hline Arbaa taourirt & 19 & 71 & 33 \\
\hline Bni bonsar & 49 & 71 & 90 \\
\hline Sidiboutmim & 137 & 220 & 154 \\
\hline Isaguen & 209 & 189 & 1916 \\
\hline Tlatketama & 100 & 260 & 221 \\
\hline Tabarrant & 218 & 120 & 178 \\
\hline Ikaouen & 150 & 107 & 422 \\
\hline
\end{tabular}

The communes ikaouen; issaguen; bni ammart; bni hdifa and bni boufrah which do not have adequate management of liquid and solid waste, have a high rate of diarrhea cases in children under five years.
Based on a survey of rural households in the province of Al- Hoceima, the management of human excrement is essentially autonomous through septic tanks, latrines or directly in nature. This exposes source water to pollution from wastewater that is released into the wild or by infiltration at septic tanks. The quality and availability of water have an impact on children's diarrheal diseases through consumption, food preparation, personal hygiene, and hygiene in the household.

\subsection{Liquid and solid sanitization}

Sanitation is strongly associated to public health because of the many diseases related to an unhealthy environment. Proximity to wastewater can lead to fecal-oral disease (diarrhea, typhoid, hepatitis, cholera), or vector-related disease (malaria). Poor environmental sanitation (excreta management, water drainage) and poor hygiene contribute to deteriorating population health. (Fig.4)

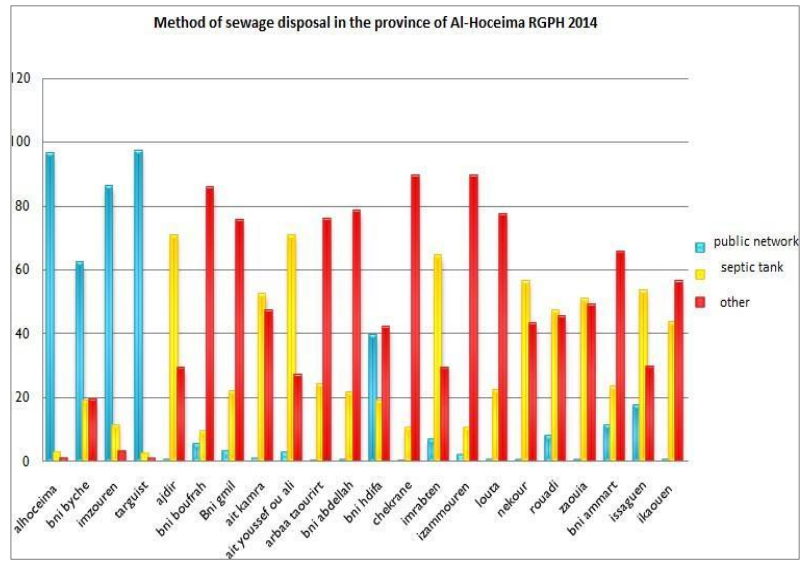

Fig. 4: Method of sewage disposal in the province of $\mathrm{Al}-$ Hoceima (RGPH)

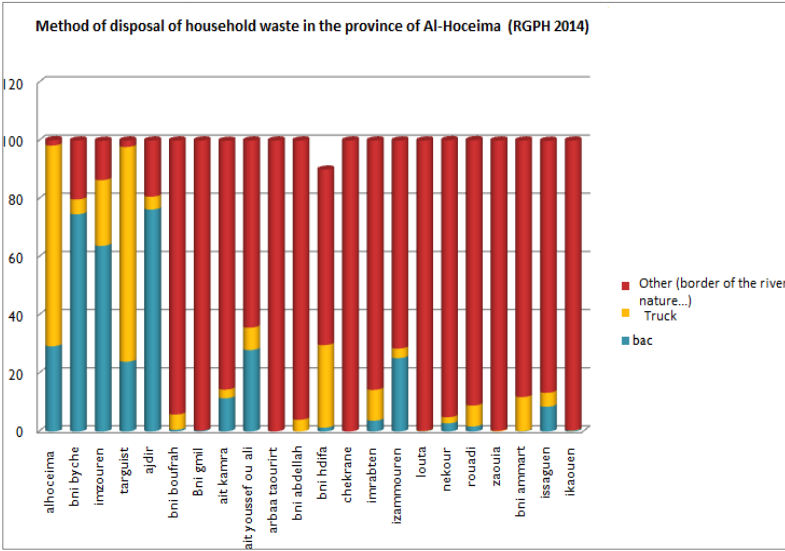

Fig. 5. Method of disposal of household waste in the province of Al-Hoceima (RGPH 2014)

\subsection{Bacteriological water quality}

The results of bacteriological analyses of the water revealed that all the wells and sources collected were contaminated. Bacteriological pollution indicator germs are $37^{\circ} \mathrm{C}$ coliform bacteria, $44^{\circ} \mathrm{C}$ thermo-tolerant coliform bacteria, and $37^{\circ} \mathrm{C}$ enterococci. Several factors could explain bacteriological pollution: 
- Environmental and Population Behavior Factors.

- Lack of hygiene rules, use of unsuitable containers.

- Water sources near septic tanks and latrines, landfill of sewage sludge in the ground.

These causes are similar to those found in the studies conducted by El Haissouffi et al. [8] on groundwater pollution in Fez and on the Physico-chemical and bacteriological quality of groundwater in sais plain [9]. Other researchers [10-12] found in their results that water contamination is the result of unsanitary user activities or the use of unsanitary equipment (buckets, rope, lid, flange, lack of personal hygiene, etc.)

\section{Conclusion}

The results of the bacteriological analysis of collective water points show very high concentrations of fecal contamination germs at all points without exception, which exposes the population to the risks of waterborne diseases and diarrhea especially in children less than five years of age.

To avoid the possibility of any health risk it is recommended to proceed to:

-Public awareness of groundwater hygiene and management is needed to improve their quality of life and health;

-Raising public awareness of best hygiene practices and sound water management.

-Continuation and reinforcement of treatment of collective water points;

-Adequate protection for well construction limits sources of water contamination. An analysis must be made at the time of the well construction and at least once a year to determine whether or not the water is potable. The well must be cleaned upon commissioning, annually, and after accidental pollution.

-The initiation of simple wastewater management processes, which will avoid the dumping of wastewater into the open air; by the application of rural sanitation and by-product recovery guide in Morocco (in an AGIRE integrated water resources management support program).

\section{ACKNOWLEDGMENT}

Special thanks to CNRS for its support (G.n: PPR2/2016/05) and the Environmental Health Technicians of the Al-Hoceima Health Delegation, the Chief Medical Officer of the SRES, as well as anyone who has given any support to this work.

\section{References}

1. International forum, the World Water Conference in Argentina, adopted by the United Nations General Assembly. (2000)

2. Report published by the World Health Organization (WHO) and Un-water. (2006)

3. MATEE ministère de l'aménagement du territoire de l'eau et de l'environnement, rapport final gestion de la demande en eau en méditerranée, progrès et politique. (2007)
4. J.Rodier, B. Legube, N. Merlet, l'analyse de l'eau, 9ème édition, Chap. D part. 6 (2009) 1063

5. K. El Ouedghiri, A. El Oualti, M. El Ouchy, F. Zerrouq, F.O. Chahdi, \& A. E. O. Lalami. J. Mater. Environ. Sci, 5, 2284-2292 (2014)

6. H. El Haissoufi, S. Berrada, M. Merzouki, M. Aabouch, L. Bennani, M. Benlemlih, M.Idir, A. Zanibou, Y. Bennis, A. ElOualilami, J. Indust Micro Sanitary and Environ, 5, 37-68 (2011)

7. N. Nouayti, D. Khattach, \& M.Hilali, J. Mater. Environ. Sci, 6, 1068-1081 (2015)

8. A. Chaïeb, \& D. Khattach, J. Mater. Environ. Sci. (2004)

9. S. Lotfi, M. Chakit, M. Najy., F.Z. Talbi, A. Benchahid, K. El Kharrim, \& D. Belghyti, Egy. J. Aqua Bio Fisheries, 24, 509-524 (2020)

10. M. Benajiba, Y. Saoud, A. Lamribah, M. Ahrikat, N. Amajoud \& O. Ouled- Zian, J. Water Sci, 26 (2013)

11. S. Ait Benichou, A. Ait Boughrous, H. El Ouarghi, S. Bengamra, M.A. Aboulhassan, H. Amhamdi., J. Mater. Environ. Sci, 9, (2018)

12. R.M. Toklo, N. Topanou, A.F. Togbe, P. DossouYovo, \& Coulomb, Res J. Chem Sci, 49-54 (2015)

13. R. Bain, R. Cronk, J. Wright, H. Yang, T. Slaymaker \& J. Bartram, PLoS Med, 11, e1001644 (2014)

14. RGPH 2014, Données démographiques et socioéconomiques de la population rurale (hors nomades) par douar selon le Recensement général de la population et de l'habitat de (2014)

15. SNIMA, NORME MAROCAINE 03.7.001. Qualité des eaux d'alimentation humaine élaborée par le comité technique de normalisation des eaux d'alimentation humaine éditée et diffusée par le service de normalisation industrielle Marocaine (SNIMA), 14 (1991)

16. O. M. de la Santé, Directives de qualité pour les eaux de boisson, 1 (1994)

17. Recommandation. Organisation mondiale de la santé 2e edition.

18. MATEE Ministère de l'Aménagement du Territoire, de l'Eau et de l'Environnement, Rapport sur l'état de l'environnement du Maroc, Département de l'Environnement, Observation National de l'Environnement du Maroc, 296 (2001)

19. A. Mecke, I. Lee, J.R. Baker jr, M.M. Banaszak Holl, B.G. Orr, Eur. Phys. J. E 14, 7 (2004)

20. M. Ben Rabha, M.F. Boujmil, M. Saadoun, B. Bessaïs, Eur. Phys. J. Appl. Phys. (to be published)

21. F. De Lillo, F. Cecconi, G. Lacorata, A. Vulpiani, EPL, 84 (2008)

22. L.T. De Luca, Propulsion physics, EDP Sciences, Les Ulis. (2009)

23. G. Plancque, D. You, E. Blanchard, V. Mertens, C. Lamouroux, in Proceedings of the International Congress on Advances in Nuclear Power Plants, ICAPP, Nice, France, 2-5 (2011) 